\title{
Vitamin D level, lipid profile, and vitamin D receptor and transporter gene variants in sickle cell disease patients from Kurdistan of Iraq
}

\author{
Abdalla Hussein Hama \\ Kermanshah University of Medical Sciences \\ Ebrahim Shakiba \\ Kermanshah University of Medical Sciences \\ Zohreh Rahimi ( $\nabla$ rahimizus@yahoo.com ) \\ Mehran Karimi \\ Shiraz University of Medical Sciences \\ Hadi Mozafari \\ Kermanshah University of Medical Sciences \\ Omed Adnan Abdulkarim \\ University of Kurdistan
}

Kermanshah University of Medical Sciences https://orcid.org/0000-0001-7589-3307

\section{Research Article}

Keywords: SCD, Vitamin D, lipid profile, VDR FoKI, VDR Taql, GC

Posted Date: March 26th, 2021

DOI: https://doi.org/10.21203/rs.3.rs-363583/v1

License: (1) This work is licensed under a Creative Commons Attribution 4.0 International License. Read Full License 


\section{Abstract}

Background. Sickle cell disease patients are susceptible to the development of vitamin D deficiency. Vitamin D through binding to vitamin receptor (VDR) exerts its function and affects gene transcription in target tissues. Also, VDR variants could affect bone mineral density.

Methods. In a case-control study 101 sickle cell disease patients including 61 SS, 39 S/ $\beta$-thalassemia, and 1 SD along with 110 healthy individuals from Kurdistan of Iraq were studied. The lipid profile, vitamin D level, Fokl, and Taql variants of VDR and group-specific component (GC) were detected using the standard enzymatic method, the immunodiagnostic systems limited EIA kit and PCR-RFLP methods, respectively.

Results. Around 93 and $82 \%$ SS and $S / \beta$ thalassemia patients, respectively had vitamin $D$ deficiency compared to $83 \%$ healthy individuals. Severe vitamin D deficiency $(<10 \mathrm{ng} / \mathrm{ml})$ was detected in $78.7 \%$ of SS patients. Plasma levels of total cholesterol, HDL-C, and LDL-C in SCD patients were significantly lower compared to controls. Vitamin D levels were negatively correlated to TG and positively correlated to total cholesterol and HDL-C. The frequencies of the $C$ allele of Fokl were $81.7(p=0.003), 80.2(p=0.034)$, and $84.6 \%$ $(p=0.011)$ in all SCD, SS, and SS/ $\beta$ thal patients, respectively compared to $69.1 \%$ in controls. However, no significant difference was detected by comparing the frequencies of VDR Taql and GC polymorphisms between SCD patients and controls.

Conclusion. In the present study we found hypocholesterolemia, high prevalence of VDR FokI C allele, and low vitamin D level among children and adults with SCD patients from Kurdistan of Iraq.

\section{Introduction}

The mutation of $\beta^{S}$ (Cd6 Glu $>$ Val) in a homozygous state causes a serious illness, sickle cell anemia (SCA), with a generally shortened life span. The severity of the combined heterozygote state of $\mathrm{Hb} \mathrm{S} / \beta$-thalassemia is variable according to the amount of $\mathrm{Hb}$ A production (1).

In SCA and homozygous $\beta$-thalassemia patients compared to normal individuals decreased cholesterol concentrations has been reported. The hemolytic stress was associated with a significant reduction in plasma lipid levels [total cholesterol, low density lipoprotein-cholesterol (LDL-C) and, high density lipoproteincholesterol (HDL-C)] except for triglycerides (TG) in SCA and sickle/ $\beta$-thalassemia patients compared to sickle cell trait and normal individuals (1). Also, among children and adolescents with major $\beta$-thalassemia, the levels of total cholesterol, LDL-C, and HDL-C were significantly lower and the TG was significantly higher compared to healthy controls (2).

Vitamin D deficiency is a major global health problem. In SCD patients, vitamin D deficiency (VDD) is highly prevalent, reaching up to $96 \%$ of the population (3). SCD patients are susceptible to the development of vitamin $\mathrm{D}$ deficiency due to decreased appetite or reduced nutrient absorption, increased basal metabolic rate with higher nutritional demands to compensate anemia, decreased conversion of vitamin $D$ to its active form due to renal impairment, and lower levels of vitamin D binding protein levels in the inflammatory state of SCD. So, it is important to assess the vitamin D levels in patients with SCD especially in children with SCD (4). VDD may contribute to too many complications of SCD. Muscle and bone pain may mimic acute sickle cell pain or 
chronic pain syndrome. Also, some bone complications of SCD may be caused or at least exacerbated by VDD (3). Further, in SCD, respiratory infection and asthma may lead to respiratory complications that are the leading cause of morbidity and mortality. Vitamin $D$ has various immune functions including immune tolerance and the control of the adaptive and innate immune responses. Vitamin $D$ deficiency is associated with susceptibility to severe infections, and in children association between hypovitaminosis $D$ and respiratory infection especially tuberculosis has been reported (5).

The levels of 25(OH)-D are influenced by genetic variation in receptors and other components involved in vitamin D metabolism (6).

The carrier of vitamin $D$ and its metabolites in the circulation is vitamin $D$ binding protein that is encoded by a gene named group-specific component (GC). The active form of vitamin D, 1, $25(\mathrm{OH})$ 2-D3, through binding to the nuclear vitamin $\mathrm{D}$ receptor (VDR) that forms a heterodimer with the retinoid-X receptor (RXR) exerts its function and affects gene transcription in target tissues (7).

The aims of the present study were to detect the vitamin D level, lipid profile, and VDR variants of Fokl, Taql and GC variants in SCD patients from Kurdistan of Iraq.

\section{Materials And Methods}

\section{Sample}

We studied 101 sickle cell disease patients including 57 males and 44 females [61 SS (15.9 \pm 9.6 years), $39 \mathrm{~S} /$ $\beta$-thalassemia (15.8 \pm 7.9 years), and 1 SD (6 years)] along with 110 healthy individuals ( 59 males and 51 females) with the mean age of $15.3 \pm 8.5$ years from Duhok-Jincenter for pediatric hemato-oncology and Qaladze Public Hospital in Kurdistan of Iraq. Among patients $62(61.4 \%)$ individuals aged $\leq 18$ years and in controls $68(61.8 \%)$ subjects aged $\leq 18$ years.

Diagnosis of patients was based on laboratory tests and molecular analysis using Dde I restriction enzyme for detection of the presence of the sickle gene.

\section{Biochemical analysis}

\section{Lipids}

Total serum cholesterol (TC), TG, and HDL-C levels were measured by the standard enzymatic method (Pars Azmoon kit, Tehran, Iran). The serum low LDL-C was calculated as follows: LDL-C=total cholesterol- (HDLC+TG/5).

\section{Vitamin D}

Vitamin D status was detected by the measurement of the serum level of $25(\mathrm{OH})$-D, the circulating form of the vitamin D, using the immunodiagnostic systems limited EIA kit. Severe vitamin D deficiency was defined as the level $\leq 10 \mathrm{ng} / \mathrm{mL}$, the deficiency was defined as the level $>10$ to $\leq 20 \mathrm{ng} / \mathrm{mL}$, and insufficiency was defined as level $>20$ to $<30 \mathrm{ng} / \mathrm{mL}$ (8). 


\section{Genotyping}

The phenol-chloroform method was used for the extraction of DNA from the leukocyte of the EDTA-treated whole blood (9).

The Fokl T>C (rs2228570) in exon 2 and the Taql T>C (rs731236) in exon 9 of the VDR gene were detected by polymerase chain reaction-restriction fragment length polymorphism (PCR-RFLP) method as previously described (10). The GC rs7041 was identified by the PCR-RFLP method using the Haell restriction enzyme (7). Informed written consent was obtained from patients or from the next-of-kin study. The Ethics Committee of Kermanshah University of Medical Sciences approved the study and the study was in accordance with the principles of the Declaration of Helsinkill.

\section{Statistical analysis}

The significance of differences in the frequencies of genotypes and alleles of Fokl, Taql, and GC polymorphisms between groups was calculated using the Chi-square test. The Odds ratios (OR) as the estimates of relative risk for the disease were calculated, and $95 \%$ confidence intervals (Cl) were detected by SPSS logistic regression software. A two-tailed Student t-test was used for comparing quantitative variables. The SPSS (SPSS Inc., Chicago, IL) statistical software package version 16.0 was used for statistical analysis. Statistical significance was considered at $p<0.05$.

\section{Results}

\section{Haematological characteristics}

Table 1 indicates the hematological characteristics of SCD patients. The HbS levels were $66 \pm 14.9,63 \pm 14.6$, and $28.8 \%$, in SS, S/ $\beta$ thal, and SD patients, respectively. The Hb F levels were 19.8 $\pm 17.3,19.1 \pm 12.1$, and $24.8 \%$, in SS, $S / \beta$ thal, and SD patients, respectively.

\section{Vitamin D level and Lipid profile}

The level of vitamin $D$ was significantly lower $(10.8 \pm 5.7 \mathrm{ng} / \mathrm{ml}, \mathrm{p}=0.007)$ comparing all SCD patients to controls $(13.5 \pm 8.4 \mathrm{ng} / \mathrm{ml})$. The vitamin D levels were $9.7 \pm 5,12 \pm 6.5$, and $7.9 \mathrm{in} S \mathrm{~S}, \mathrm{~S} / \beta$ thal, and SD patients, respectively. The level of vitamin $D$ was significantly lower in SS patients than in controls $(P<0.001)$. Fifty seven out of 61 SS patients (93.4\%) had vitamin D level $\leq 20 \mathrm{ng} / \mathrm{ml}$. In S/ $\beta$ thal patients 32 out of 39 patients (82.1\%) had vitamin D level $\leq 20 \mathrm{ng} / \mathrm{ml}$. In controls, 91 out of 110 individuals $(82.7 \%)$ had vitamin D deficiency $(\leq 20 \mathrm{ng} / \mathrm{ml})$. Severe vitamin D deficiency $(<10 \mathrm{ng} / \mathrm{ml})$ was detected in 70 out of $101 \mathrm{SCD}$ patients (69.3\%) compared to 52 out of 110 controls $(47.3 \%, p=0.001)$. In SS patients 48 out of 61 patients $(78.7 \%)$ had severe vitamin $\mathrm{D}$ deficiency.

Total cholesterol, HDL-C, and LDL-C levels in all SCD patients were significantly lower $(p<0.001)$ than controls. Comparing SCD patients according to genotype with controls demonstrated that total cholesterol, $\mathrm{HDL}-\mathrm{C}$, and LDL-C were significantly lower in SS and $S / \beta$ thal patients compared to controls $(p<0.001)$. 
There was a significant difference in total cholesterol, TG, and HDL-C levels concerning the vitamin D levels. Table 3 indicates vitamin D levels were negatively correlated to TG $(p=0.039)$ and positively correlated to total cholesterol $(p=0.006)$ and HDL-C $(p<0.001)$.

\section{Genotyping}

Distribution of Fokl (SNPrs2228570) genotypes was in the Hardy-Weinberg equilibrium in SCD patients $\left(\chi^{2}=\right.$ $0.1, p>0.1)$ and in controls $\left(\chi^{2}=2.45, p>0.1\right)$. Table 4 indicates the frequency of Fokl genotypes, and alleles in patients and controls. The frequencies of the $C$ allele of Fokl were $81.7(p=0.003), 80.2(p=0.034)$, and 84.6\% $(p=0.011)$ in all SCD, SS, and SS/ $\beta$ thal patients, respectively compared to $69.1 \%$ in controls.

The frequencies of Taql (rs731236) genotypes was in the Hardy-Weinberg equilibrium in SCD patients $\left(\chi^{2}=\right.$ $0.78, p>0.1)$ and controls $\left(\chi^{2}=0.61, p>0.1\right)$. Distribution of Taql genotypes and alleles among SCD patients and controls is depicted in Table 5. The frequencies of the $C$ allele was 39.3 , and $47.4 \%$ in SS and S/thal patients, respectively compared to $36.8 \%$ in controls $(p>0.05)$.

Distribution of GC (rs7041) genotypes was in the Hardy-Weinberg equilibrium only in SCD patients $\left(\chi^{2}=0.41\right.$, $p>0.1)$. The frequencies of $G$ allele were 54.1 , and $52.6 \%$ in SS and $S / \beta$ thal patients, respectively and was $53.2 \%$ in controls $(p>0.05)$ (Table 5$)$.

\section{Discussion}

In the present study around $94 \%$ of SS and about $81 \%$ of $S / \beta$ thal patients had VDD. However, around $83 \%$ of healthy individuals had VDD. The incidence of VDD is between 20 to $80 \%$ in some Middle Eastern counties. Lower vitamin $\mathrm{D}$ levels have been associated with lower levels of hemoglobin and hematocrit and with higher reticulocyte counts among Egyptian children with SCD, suggested vitamin D deficiency might increase hemolysis of RBCs in these patients (11). In patients with SCD, the prevalence of VDD is increased which might exacerbate by enhanced erythropoiesis and basal metabolic rate, inadequate dietary intake, and reduced nutrient absorption due to inflammatory damage of the intestinal mucosa (12). Our study demonstrated around 78\% of SCA patients from Kurdistan of Iraq had severe VDD. In a study of 139 children (aged 7.9-15.1 years) with SCA, severe vitamin D deficiency ( $<10 \mathrm{ng} / \mathrm{mL}$ ) was detected in $64.0 \%$ and only $2.2 \%$ had a sufficient level of vitamin D (>30 ng/mL). Moreover, vitamin D levels were associated with the pulmonary function (13).

Vitamin D should be carefully evaluated in SCA children because developing VDD in these children is higher than in healthy individuals due to high melanin levels in the skin, low levels of physical activity, and low food intake in these children (14). It has been suggested that hemoglobin released by chronic hemolysis could contribute to vitamin D deficiency in SCD patients (15). Increased respiratory infections, muscle weakness, and enhance risk of falls and microlesions are associated with VDD. Vitamin D deficiency is associated with bone weakness and painful crises and increased vitamin D level through supplementation is positively associated with functional and physical capacity (14). In a randomized clinical trial in pediatric patients with SCD the potential benefit of vitamin D for preventing respiratory complications has been indicated with both monthly high- and standard-dose vitamin D (16). 
Our study showed plasma levels of total cholesterol, HDL-C, and LDL-C in SCD patients were significantly lower $(p<0.001)$ compared to controls and SCD patients had hypocholesterolemia. The hemolytic stress is associated with a significant reduction in total cholesterol, LDL-C, and HDL-C in SCA and sickle/ $\beta$-thalassemia patients compared to sickle cell trait and healthy individuals (1). A cohort study from the USA, studying 365 SCD patients and controls, demonstrated significantly decreased plasma levels of total cholesterol, HDL-C, and LDL-C in SCD patients compared to healthy controls (17). Also, previously we reported lower total cholesterol, HDL-C, and LDL-C in SCD patients from Southern Iran compared to controls (1).

In the present study, vitamin D levels were negatively correlated to TG and positively correlated to total cholesterol and HDL-C. The levels of vitamin D have been negatively associated with TG and positively correlated to serum HDL-C. In pediatrics, SS and S/ $\beta$-thalassemia patients with low vitamin $D$ levels significantly higher VLDL levels were detected compared to controls (18). In a report from Turkey, among SCD patients it was indicated that vitamin $\mathrm{D}$ levels were negatively correlated to TG and positively correlated to total cholesterol and HDL-C (18). Inadequate vitamin D level is associated with chronic inflammation, and with low levels of HDL-C and those SCD patients with the lower levels of vitamin D had lower HDL-C values (< $40 \mathrm{mg} / \mathrm{dl}$ ). Low HDL-C values could be considered as a prognostic marker of hemolysis and endothelial dysfunction (4). Also, irrespective of vitamin D status, SCD patients had significantly higher TG levels than controls. Hypertriglyceridemia in SCD is linked to chronic inflammation (18).

Since 1, $25(\mathrm{OH})$ 2-D3 through binding to VDR exerts its effect, the presence of polymorphism in the VDR might modulate the VDR expression. The $\mathrm{C}$ allele of VDR Fokl polymorphism does not have the first ATG, and translation starts at the second ATG. So, the presence of this allele producing a shorter VDR protein by 3 amino acids compared with the T allele (10). In the present study, significantly higher frequency of the Fokl $\mathrm{C}$ allele was detected in SS and S/ $\beta$ thal patients than controls. In beta-thalassemia major patients the polymorphisms of Fokl (FF or CC genotype) was significantly associated with the low bone mineral density of the lumbar spine. But Taql polymorphism was not associated with bone mineral density. It has been suggested that the VDR polymorphism can be used as an additional test in individuals susceptible to osteoporosis for early prevention (19).

The frequency of the CC genotype of FoKI was around 33\% in Egyptian SCD children (20). Their study reported that the Fokl polymorphism is associated with low bone mineral density at the forearm and lumbar spine and is a useful genetic marker in determining the bone mineral density and osteoporosis risk (20). However, in our study, the frequencies of this genotype were around 64 and $66 \%$ in SS and S/ $\beta$ thal patients, respectively. The high prevalence of the FoKI C allele along with the high prevalence of severe deficiency of vitamin D among our SCA patients should be considered as the serious risk factors for reduced bone mineral density and osteoporosis that ask for urgent supplementation of cholecalciferol in SCD patients from Kurdistan of Iraq. Vitamin D supplementation has improved the pain symptoms in an SCD patient with VDD and severe osteoporosis (6). In monozygotic twins (male or female pairs) supplementation of cholecalciferol at the concentration of 2000 IU for 2 months increased circulating serum vitamin D levels and VDR mRNA expression (21). Also, the VDR expression has been reported to be correlated with higher $250 \mathrm{H}-\mathrm{D}$ levels suggested that the VDR is positively regulated by $1,25-(\mathrm{OH})(22)$. 
In the present study, the frequencies of Taql (rs731236) genotypes and alleles were not significantly different comparing SCD patients with controls. The absence of association between Taql polymorphism with bone mineral density has been reported (19).

Vitamin D binding protein encoded by the GC gene binds to $25(\mathrm{OH})$-D in plasma and serves as a reservoir, and prolongs the $25(\mathrm{OH})$-D half-life (22). In our study, we did not detect a statistically significant difference in the frequencies of genotypes and alleles of GC (rs7041) between SCD patients and controls. It has been reported that the GC (rs7041) polymorphism is related to a different binding affinity for 25 (OH)-D. Reduced binding of $25(\mathrm{OH})$-D to GC protein might decrease the levels of 25(OH)-D and other vitamin D metabolites. In some but not all studies the GC polymorphism was significantly associated with lower serum levels of $25(\mathrm{OH})$-D. The association of GC polymorphism with $25(\mathrm{OH})$-D is ethnic dependent as has been reported in some specific ethnic populations such as Arab and South Asian populations (7). We did not detect an association between $25(\mathrm{OH})$-D level and GC polymorphism.

In SCD patients metabolic demands on the liver might reduce the capacity of vitamin D binding protein synthesis (6). Lower levels of 25-OHD levels were associated with decreased expression of GC and VDR genes (22).

In conclusion, our study indicated the presence of hypocholesterolemia in sickle cell anemia and $S / \beta$ thal patients from Kurdistan of Iraq. Also, we demonstrated a high prevalence of severe vitamin D deficiency in SCD patients from this area. Moreover, a significantly high frequency of the VDR Fokl allele was found among sickle cell anemia and $S / \beta$ thal patients. Our study confirms induced hypocholesterolemia by hemolytic stress and positive association between vitamin $D$ and HDL-C levels that shows adverse effects of low HDL-C values on hemolysis in the presence of low vitamin D levels. On the other hand, VDD is associated with comorbidities and considering the high prevalence of VDR FokI $\mathrm{C}$ allele with an adverse effect on bone mineral density there is concern about children and adults with SCD patients that asks urgent and immediate intervention and supplementation of vitamin $\mathrm{D}$ in their diet.

\section{Declarations}

\section{CONFLICTS OF INTEREST}

The authors declare that they have no conflicts of interest.

\section{ACKNOWLEDGMENT}

This study was performed in partial fulfillment of the requirements for MSc degree of Abdalla Hussein Hama, Kermanshah University of Medical Sciences, Kermanshah, Iran.

\section{References}

1. Rahimi Z, Merat A, Haghshenass M, Madani H, Rezaei M, Nagel RL (2006) Plasma lipids in Iranians with sickle cell disease: hypocholesterolemia in sickle cell anemia and increase of HDL-cholesterol in sickle 
cell trait. Clin Chim Acta 365(1-2):217-220

2. Madani H, Rahimi Z, Manavi-Shad M, Mozafari H, Akramipour R, Vaisi-Raygani A, Rezaei M, MalekKhosravi S, Shakiba E, Parsian A (2011) Plasma lipids and lipoproteins in children and young adults with major $\beta$-thalassemia from western Iran: influence of genotype. Mol Biol Rep 38(4):2573-2578

3. Chen Z, Pang Y, Liu X, Wang X, Deng Z, Sun X (eds) (2001) The Metabolic and Molecular. Bases of Inherited Disease. McGraw-Hill, Inc, Health Professions Division Citeseer.

4. Mandese V, Bigi E, Bruzzi P, Palazzi G, Predieri B, Lucaccioni L, Cellini M, lughetti L (2019) Endocrine and metabolic complications in children and adolescents with sickle cell disease: an Italian cohort study. BMC Pediatrics 19:56

5. Ariganjoye R. Pediatric hypovitaminosis D (2017) Molecular perspectives and clinical implications. Global Pediatric Health 4:1 - 7

6. Tayo BO, Akingbola TS, Salako BL et al (2014) Vitamin D levels are low in adult patients with sickle cell disease in Jamaica and West Africa. BMC Hematology 14:12

7. Ghorbani Z, Shakiba M, Rezavand N, Rahimi Z, Vaisi-Raygani A, Rahimi Z, Shakiba E (2021) Gene variants and haplotypes of Vitamin D biosynthesis, transport, and function in preeclampsia. Hypertens Pregnancy 40(1):1-8

8. Nolan VG, Nottage KA, Cole EW, Hankins JS, Gurney JG (2015) Prevalence of vitamin D deficiency in sickle cell disease: A systematic review. PLoS ONE 10(3):e0119908

9. Bahrehmand F, Vaisi-Raygani A, Kiani A et al (2012) Matrix metalloproteinase-2 functional promoter polymorphism G1575A is associated with elevated circulatory MMP-2 levels and increased risk of cardiovascular disease in systemic lupus erythematosus patients. Lupus 21(6):616-624

10. Rezavand N, Tabarok S, Rahimi Z, Vaisi-Raygani A, Mohammadi E, Rahimi Z (2019) The effect of VDR gene polymorphisms and vitamin $D$ level on blood pressure, risk of preeclampsia, gestational age, and body mass index. J Cell Biochem 120(4):6441-6448

11. Hamdy M, Salama N, Maher G, Elrefaee A. Vitamin D and nonskeletal complications among egyptian sickle cell disease patients. Advances in Hematology. 2018; 2018

12. Samson KLI, McCartney H, Vercauteren SM, Wu JK, Karakochuk CD (2018) Prevalence of vitamin D deficiency varies widely by season in Canadian children and adolescents with sickle cell disease. $J$ Clin Med 7:14

13. Jackson TC, Krauss MJ, Debaun MR, Strunk RC, Arbeláez AM (2012) Vitamin-D deficiency and comorbidities in children with sickle cell anemia. Pediatr Hematol Oncol 29(3):261-266

14. Oliveira JF, Vicente NG, Pontes Santos JP, Silva Weffort VR (2015) Vitamin D in children and adolescents with sickle cell disease: an integrative review. Rev Paul Pediatr 33(3):349-354

15. Gliozzi ML, Rbaibi Y, Long KR, Vitturi DA, Ora A, Weisz OA (2019) Hemoglobin alters vitamin carrier uptake and vitamin D metabolism in proximal tubule cells: implications for sickle cell disease. Am J Cell Physiology 317(5):C993-C1000

16. Lee MT, Kattan M, Fennoy I et al (2018) Randomized phase 2 trial of monthly vitamin D to prevent respiratory complications in children with sickle cell disease. Blood Adv 2(9):969-978 
17. Zorca S, Freeman L, Hildesheim M, Allen D, Remaley AT, Taylor JG et al (2010) Lipid levels in sickle-cell disease associated with haemolytic severity, vascular dysfunction and pulmonary hypertension. $\mathrm{Br} \mathrm{J}$ Haematol 149(3):436-445

18. Oztas Y, Unal S, Eskandari G, Tamer L, Ozgunes N. Vitamin D, Deficiency (2018) and Its Association with Inflammatory Markers, Lipid Profile and Regulatory T-cells in Pediatric Sickle Cell Disease Patients. Indian Journal of Hematology Blood Transfusion 34(3):480-485

19. Singh K, Kumar R, Shukla A, Phadke SR, Agarwal S (2012) Status of 25-hydroxyvitamin D deficiency and effect of vitamin $D$ receptor gene polymorphisms on bone mineral density in thalassemia patients of North India. Hematology 17:5,291-296

20. Hamed HM, Galal A, El-Ghamrawy M et al (2010) Vitamin D receptor polymorphisms and indices of bone turnover and bone mass in Egyptian children with sickle cell disease. Research Journal of Medicine Medical Sciences 5(1):1-7

21. Medeiros deO, Borges MV, Soares AA et al (2020) The impact of vitamin D supplementation on VDR gene expression and body composition in monozygotic twins: randomized controlled trial. Sci Rep 10(1):11943

22. Han J, Zhang X, Santosh L, Saraf SL et al (2018) Risk factors for vitamin D deficiency in sickle cell disease. Br J Haematol 181(6):828-835

\section{Tables}

Table 1. Hematological characteristics of studied patients.

\begin{tabular}{|c|c|c|c|c|c|c|c|c|c|}
\hline $\begin{array}{l}\text { ents } \\
\text { a) }\end{array}$ & Age & $\mathrm{Hb}(\mathrm{g} / \mathrm{L})$ & \%HCT & $\operatorname{RBC}\left(10^{12} / \mathrm{l}\right)$ & $\% \mathrm{HbA} 2$ & $\% \mathrm{HbF}$ & $\% \mathrm{HbS}$ & MCV(fL) & $\mathrm{MCH}(\mathrm{pg})$ \\
\hline $\begin{array}{l}\overline{l l} \\
\text { J1) }\end{array}$ & $15.83 \pm 8.92$ & $86.2 \pm 13.4$ & $25.2 \pm 4.5$ & $3.05 \pm 0.84$ & $3.38 \pm 1.3$ & $19.6 \pm 15.3$ & $64.4 \pm 15.2$ & $85.6 \pm 15.8$ & $29.6 \pm 6.0$ \\
\hline $\begin{array}{l}\text { S } \\
i 1)\end{array}$ & $15.90 \pm 9.6$ & $83.8 \pm 11.1$ & $24.0 \pm 3.8$ & $2.6 \pm 0.5$ & $2.7 \pm 0.9$ & $19.8 \pm 17.3$ & $66.0 \pm 14.9$ & $92.0 \pm 13.4$ & $32.6 \pm 4.9$ \\
\hline $\begin{array}{l}\text {-thal } \\
\text { (9) }\end{array}$ & $15.8 \pm 7.9$ & $89.5 \pm 15.5$ & $26.9 \pm 4.9$ & $3.7 \pm 0.8$ & $4.5 \pm 1.4$ & $19.1 \pm 12.1$ & $63.0 \pm 14.6$ & $74.3 \pm 12.6$ & $24.8 \pm 4.4$ \\
\hline $\begin{array}{l}\text { D } \\
\text { 1) }\end{array}$ & 6.00 & 65 & 19.3 & 2.18 & 1.3 & 24.8 & 28.8 & 88.5 & 30.2 \\
\hline $\begin{array}{l}\text { trols } \\
\text { 10) }\end{array}$ & $15.3 \pm 8.5$ & $135.5 \pm 14.5$ & $39.7 \pm 4.2$ & $4.9 \pm 0.5$ & - & - & - & $82.2 \pm 4.7$ & $28.2 \pm 2.1$ \\
\hline
\end{tabular}

- Parameters are described as Mean \pm SD

Table 2. Vitamin D level and lipid profile in patients and controls. 


\begin{tabular}{|c|c|c|c|c|c|c|c|}
\hline Group & $\mathbf{N}$ & $\begin{array}{c}\text { Age } \\
\text { (Years) }\end{array}$ & $\begin{array}{l}\text { Vitamin D } \\
\text { (ng/ml) }\end{array}$ & $\begin{array}{l}\text { Total cholesterol } \\
\text { (mg/dl) }\end{array}$ & $\begin{array}{l}\text { Triglyceride } \\
\text { (mg/dl) }\end{array}$ & $\begin{array}{c}\text { HDL } \\
\text { (mg/dl) }\end{array}$ & $\begin{array}{c}\text { LDL } \\
\text { (mg/dl) }\end{array}$ \\
\hline SS & 61 & $15.9 \pm 9.6$ & $9.7 \pm 5^{*}$ & $103.1 \pm 20.5^{*}$ & $96.2 \pm 27.9$ & $34.0 \pm 9.1 *$ & $49.2 \pm 20.7 *$ \\
\hline Male & 35 & $13.6 \pm 7.9$ & $10.2 \pm 4.7 * *$ & $102.5 \pm 18.3^{*}$ & $89.7 \pm 28.6$ & $33.9 \pm 10.4^{*}$ & $49.7 \pm 17.2^{* *}$ \\
\hline Female & 26 & $19.0 \pm 10.8$ & $8.9 \pm 5.3$ & $104.6 \pm 23.3^{*}$ & $105.1 \pm 24.8$ & $34.2 \pm 7.3 *$ & $\begin{array}{c}48 . \\
6 \pm 24.9 * *\end{array}$ \\
\hline S/thal & 39 & $15.8 \pm 7.9$ & $12.5 \pm 6.5$ & $104.0 \pm 19.8 *$ & $93.2 \pm 36.6$ & $34.5 \pm 10.1 *$ & $51.0 \pm 17.3^{* *}$ \\
\hline Male & 21 & $14.5 \pm 9.1$ & $12.7 \pm 6.7$ & $102.6 \pm 19.80 *$ & $92.43 \pm 38.8$ & $35.0 \pm 10.1 *$ & 48. \\
\hline Female & 18 & $17.3 \pm 6.2$ & $12.2 \pm 6.3$ & $106.2 \pm 20.20^{*}$ & $94.2 \pm 35.0$ & $33.8 \pm 10.4^{*}$ & $\begin{array}{c}8 \pm 17.0^{* *} \\
53.6 \pm 17.9\end{array}$ \\
\hline $\mathrm{SD}$ & 1 & 6.0 & & & & & \\
\hline Male & 1 & 6.0 & 7.9 & $68^{* *}$ & 126 & 30 & $12.8^{* *}$ \\
\hline Female & - & - & & & & & \\
\hline Controls & 110 & $15.3 \pm 8.5$ & $13.5 \pm 8.4$ & $137.3 \pm 27.1$ & $98.4 \pm 64.8$ & $54.5 \pm 14.1$ & $62.7 \pm 23.6$ \\
\hline Male & 59 & $13.8 \pm 8.5$ & $14.8 \pm 8.8$ & $135.7 \pm 27.2$ & $102.3 \pm 64.3$ & $53.3 \pm 14.9$ & $61.0 \pm 23.1$ \\
\hline Female & 51 & $17.0 \pm 8.2$ & $11.9 \pm 7.6$ & $139.1 \pm 27.3$ & $93.8 \pm 65.6$ & $56.0 \pm 13.0$ & $64.6 \pm 24.3$ \\
\hline
\end{tabular}

*Statistically significant compared to control group $(\mathrm{p}<0.001)$

** Statistically significant compared to control group $(\mathrm{p}<0.03)$

Table 3. Correlation of vitamin D level and lipid profile of patients and controls.

\begin{tabular}{cccc}
\hline Parameters mg/dl & Pearson Correlation & P value & R-square \\
\hline Cholesterol & $0.187^{* *}$ & 0.006 & 0.035 \\
Triglyceride & $-0.141^{*}$ & 0.039 & 0.02 \\
HDL-C & $0.254^{* *}$ & $<0.001$ & 0.065 \\
LDL-C & 0.06 & 0.38 & - \\
\hline
\end{tabular}

**Correlation was significant at the 0.01 level.

*Correlation was significant at the 0.05 level.

Table 4. Distribution of FoKI (rs2228570) genotypes and alleles in SCD patients and controls. 


\begin{tabular}{|c|c|c|c|c|}
\hline $\begin{array}{l}\text { FokI } \\
\text { genotypes }\end{array}$ & $\begin{array}{l}\mathrm{SS}, \mathrm{n}=61 \\
\mathrm{n}(\%)\end{array}$ & $\begin{array}{l}S / \beta \text { thal, } n=39 \\
n(\%)\end{array}$ & $\begin{array}{l}\text { All patients, } \mathrm{n}=101 \\
\mathrm{n}(\%)\end{array}$ & $\begin{array}{l}\text { Controls, } \\
\mathrm{n}=110 \\
\mathrm{n}(\%)\end{array}$ \\
\hline $\mathrm{TT}$ & $2(3)$ & $1(2.5)$ & $3(3)$ & $7(6.4)$ \\
\hline $\mathrm{TC}$ & 20 (33) & $12(30.8)$ & $32(32)$ & $54(49.1)$ \\
\hline $\mathrm{CC}$ & $\begin{array}{l}39 \text { (64) } \\
\chi^{2}=5.1^{\#}, \mathrm{p}=0.023, \mathrm{OR}=2.1 \\
95 \% \mathrm{CI},(1.1-4.2, \mathrm{p}=0.024)\end{array}$ & $\begin{array}{l}26 \text { (66.7) } \\
\chi^{2}=4.8^{\#}, p=0.028 \text { OR=2.4, } \\
95 \% C I,(1.1-5.2, p=0.03)\end{array}$ & $\begin{array}{l}66(65) \\
\chi^{2}=8^{\#}, p=0.005 \mathrm{OR}=2.3 \\
95 \% \mathrm{CI},(1.3-4.0, \mathrm{p}=0.005)\end{array}$ & 49 (44.5) \\
\hline $\begin{array}{l}\text { Alleles } \\
\mathrm{T} \\
\mathrm{C}\end{array}$ & $\begin{array}{l}25(19.8) \\
101(80.2) \\
\chi^{2}=4.47, \quad \mathrm{p}=0.034 \\
\text { OR=1.75, 95\%CI (1.03- } \\
2.96, \quad \mathrm{p}=0.036)\end{array}$ & $\begin{array}{l}12(15.4) \\
66(84.6) \\
\chi^{2}=6.5, p=0.011 \\
O R=2.4,95 \% C I(1.2-4.7 \\
p=0.012)\end{array}$ & $\begin{array}{l}37(18.3) \\
165(81.7) \\
\chi^{2}=8.8, p=0.003 \\
O R=2.0,95 \% C I(1.3-3.1 \\
p=0.003)\end{array}$ & $\begin{array}{l}68(30.9) \\
152 \\
(69.1)\end{array}$ \\
\hline
\end{tabular}

Overall $\chi^{2}$ comparing three genotypes between all SCD patients and controls was 9.37, $\mathrm{p}=0.009$.

Overall $\chi^{2}$ comparing two alleles between all SCD patients and controls was $8.8, p=0.003$.

Overall $\chi^{2}$ comparing three genotypes between $S / \beta$ thal patients and controls was $5.7, \mathrm{p}=0.056$.

***Overall $\chi^{2}$ comparing three genotypes between SS patients and controls was $5.9, \mathrm{p}=0.05$.

\# Compared to TC genotype between SS and controls.

Table 5. Distribution of TaqI (rs731236) and GC (rs7140) genotypes and alleles in patients and controls. 


\begin{tabular}{|l|l|l|l|l|}
\hline TaqI genotypes & $\begin{array}{l}\mathrm{SS}, \mathrm{n}=61 \\
\mathrm{n}(\%)\end{array}$ & $\begin{array}{l}\mathrm{S} / \beta \text { thal, } \mathrm{n}=39 \\
\mathrm{n}(\%)\end{array}$ & $\begin{array}{l}\text { All patients, } \mathrm{n}=101 \\
\mathrm{n}(\%)\end{array}$ & $\begin{array}{l}\text { Controls, } \mathrm{n}=110 \\
\mathrm{n}(\%)\end{array}$ \\
\hline TT & $23(37.7)$ & $9(23)$ & $32(31.7)$ & $42(38.2)$ \\
\hline TC & $28(46)$ & $25(64)$ & $54(53.5)$ & $55(50)$ \\
\hline CC & $10(16.3)$ & $5(13)$ & $15(14.8)$ & $13(11.8)$ \\
\hline $\begin{array}{l}\text { Alleles } \\
\text { T }\end{array}$ & $74(60.7)$ & $41(52.6)$ & $118(58.4)$ & $139(63.2)$ \\
C & $48(39.3)$ & $37(47.4)$ & $84(41.6)$ & $81(36.8)$ \\
GC genotypes & $9(14.8)$ & $12(30.8)$ & $21(21)$ & \\
TT & $37(60.7)$ & $15(38.4)$ & $52(51)$ & $25(22.7)$ \\
TG & $15(24.5)$ & $12(30.8)$ & $28(28)$ & $53(48.2)$ \\
GG & & & & $32(29.1)$ \\
Alleles & & & $93(46)$ & $103(46.8)$ \\
T & $56(45.9)$ & $37(47.4)$ & $109(54)$ & \\
G & $66(54.1)$ & $41(52.6)$ & & \\
\hline
\end{tabular}

TaqI: Overall $\chi^{2}$ comparing three genotypes between all SCD patients and controls was $1.1, \mathrm{p}=0.57$, Overall $\chi^{2}$ comparing two alleles between all SCD patients and controls was 1.0, $\mathrm{p}=0.29$.

GC: * Overall $\chi^{2}$ comparing three genotypes between all SCD patients and controls was $0.24, p=0.88$, Overall $\chi^{2}$ comparing two alleles between all SCD patients and controls was $0.01, p=0.91$. 